IZA DP No. 8699

\title{
A Theory of Wage Adjustment under Loss Aversion
}

Steffen Ahrens

Inske Pirschel

Dennis J. Snower

December 2014 


\title{
A Theory of Wage Adjustment under Loss Aversion
}

\author{
Steffen Ahrens \\ Technische Universität Berlin \\ and Kiel Institute for the World Economy \\ Inske Pirschel \\ Kiel Institute for the World Economy \\ and Christian-Albrechts University Kiel
}

Dennis J. Snower

Kiel Institute for the World Economy, Christian-Albrechts University Kiel, CEPR and IZA

\section{Discussion Paper No. 8699 \\ December 2014}

\author{
IZA \\ P.O. Box 7240 \\ 53072 Bonn \\ Germany \\ Phone: +49-228-3894-0 \\ Fax: +49-228-3894-180 \\ E-mail: iza@iza.org
}

\begin{abstract}
Any opinions expressed here are those of the author(s) and not those of IZA. Research published in this series may include views on policy, but the institute itself takes no institutional policy positions. The IZA research network is committed to the IZA Guiding Principles of Research Integrity.

The Institute for the Study of Labor (IZA) in Bonn is a local and virtual international research center and a place of communication between science, politics and business. IZA is an independent nonprofit organization supported by Deutsche Post Foundation. The center is associated with the University of Bonn and offers a stimulating research environment through its international network, workshops and conferences, data service, project support, research visits and doctoral program. IZA engages in (i) original and internationally competitive research in all fields of labor economics, (ii) development of policy concepts, and (iii) dissemination of research results and concepts to the interested public.
\end{abstract}

IZA Discussion Papers often represent preliminary work and are circulated to encourage discussion. Citation of such a paper should account for its provisional character. A revised version may be available directly from the author. 
IZA Discussion Paper No. 8699

December 2014

\section{ABSTRACT}

\section{A Theory of Wage Adjustment under Loss Aversion*}

We present a new theory of wage adjustment, based on worker loss aversion. In line with prospect theory, the workers' perceived utility losses from wage decreases are weighted more heavily than the perceived utility gains from wage increases of equal magnitude. Wage changes are evaluated relative to an endogenous reference wage, which depends on the workers' rational wage expectations from the recent past. By implication, employment responses are more elastic for wage decreases than for wage increases and thus firms face an upward-sloping labor supply curve that is convexly kinked at the workers' reference price. Firms adjust wages flexibly in response to variations in labor demand. The resulting theory of wage adjustment is starkly at variance with past theories. In line with the empirical evidence, we find that (1) wages are completely rigid in response to small labor demand shocks, (2) wages are downward rigid but upward flexible for medium sized labor demand shocks, and (3) wages are relatively downward sluggish for large shocks.

JEL Classification: D03, D21, E24

Keywords: downward wage sluggishness, loss aversion

Corresponding author:

Dennis J. Snower

Kiel Institute for the World Economy

Kiellinie 66

24105 Kiel

Germany

E-mail: Dennis.Snower@ifw-kiel.de

\footnotetext{
* This paper is part of the Kiel-INET research group on new economic thinking. Steffen Ahrens acknowledges support by the Deutsche Forschungsgemeinschaft (DFG) through the CRC 649 "Economic Risk".
} 


\section{Introduction}

This paper presents a theory of wage adjustment based on worker loss aversion, along the lines of prospect theory (Kahnemann and Tversky, 1979) and building on Ahrens, Pirschel and Snower (2014) which considers how consumer loss aversion affects price setting. The theory has distinctive implications, which are starkly at variance with major existing theories of wage adjustment but consonant with the empirical evidence. In particular, the theory implies that (1) for small labor demand shocks, wages are fully rigid, (2) for medium-sized shocks there is upward wage adjustment for positive shocks, but complete downward wage rigidity for negative shocks and (3) for large shocks, wages decline less strong to negative shocks than they increase to equiproportionate positive shocks. In short, our theory can explain the occurrence of wage rigidity in the presence of small labor demand variations, downward wage rigidity but upward wage adjustment to intermediate labor demand variations, and downward wage sluggishness in the presence of large shocks.

While current theories of wage adjustment fail to account for these empirical regularities, this paper offers a theoretical rationale. The basic idea underlying our theory is simple. In the spirit of prospect theory, the utility losses from wage decreases are weighted more heavily than the utility gains from wage increases of equal magnitude. Consequently, employment responses are more elastic to wage decreases than to wage increases. The result is a kinked labor supply curve, for which the kink depends on the workers' reference wage. In the spirit of Köszegi and Rabin (2006), we model the reference wage as the workers' rational wage expectations.

The kink of the labor supply curve implies that wages are rigid in response to sufficiently small labor demand shocks, but wages adjust asymmetrically to larger shocks. The reason for this asymmetry is straightforward. Firms foresees that their wage setting decision has an effect on the worker's reference wage. Therefore, a labor demand shock not only produces a change in employment following the firm's immediate wage setting decision, but also the resulting change in the workers' reference wage. A rise in the reference wage raises the firms' long-run profits (since the reference wage is located at the kink of the labor supply curve), whereas a fall in the reference wage lowers long-run profits. On this account, positive labor demand shocks lead to wage increases, while negative labor demand shocks may lead to relatively little if any downward wage adjustment. $^{1}$

\footnotetext{
${ }^{1}$ Our theory may help shed light on asymmetric effects of monetary policy, though such implications lie beyond the scope of this paper. First it is relevant to the literature on short-run monetary policy, which has asymmetric effects under downward nominal wage rigidity (e.g. McDonald and Sibly, 2001; Carlsson and Westermark, 2008; Fahr and Smets, 2010). Second, while symmetric nominal rigidities give rise to a long-run Phillips curve which is virtually vertical (e.g. Goodfriend and King, 1997; Khan et al., 2003), downward nominal wage rigidity leads to a significantly non-vertical long-run Phillips curve, thereby generating substantial long-run real effects of monetary policy on output and employment for negative shocks, as shown by Kim and Ruge-Murcia (2009, 2011), Fagan and Messina (2009), Fahr and Smets (2010), Benigno and Ricci (2011) and Abo-Zaid (2013). In all of these latter contributions,
} 
The paper is structured as follows. Section 2 reviews the relevant literature. Section 3 presents our general model setup. In section 4 we analyze the effects of various demand shocks on wages, both analytically and numerically. Section 5 concludes.

\section{Relation to the Literature}

In this section, we consider the empirical evidence suggesting that nominal wages are (imperfectly) downward rigid, while they are upward flexible. In particular, ample microeconomic evidence points towards three important stylized facts, namely that (i) there is a high incidence of nominal wage freezes, (ii) there is a lack of nominal wage cuts in normal times, and (iii) wage cuts take place in severe downturns.

This evidence implies that the distribution of wage changes spikes at zero and contains much fewer observations below zero than above. Such a distribution of wage changes is documented for a wide variety of industrialized countries. For the United States, McLaughlin (1994), Card and Hyslop (1996), Kahn (1997), and Altonji and Devereux (1999) derive such evidence from the Panel Study of Income Dynamics, while Akerlof et al. (1996), Lebow et al. (1999), Gottschalk (2005), and Dickens et al. (2007) find this distribution based on employer reports, social security files, and several different household surveys. Based on national wage and income surveys as well as on employer reports, Smith (2000), Agell and Lundborg (2003), Nickell and Quadrini (2003), Fehr and Goette (2005), Bauer et al. (2007), Dickens et al. (2007), Babecký et al. (2010), Böckerman et al. (2010), and Sigurdsson and Sigurdardottier (2012), provide this evidence for a large sample of European economies, while Kimura and Ueda (2001), Cobb and Opazo (2008), and Iregui et al. (2009) find this for Japan, Chile, and Colombia, respectively.

While all these studies find that nominal wage cuts are rare, they do happen and commonly take place in times of severe financial distress, such as long lasting and deep recessions or any other sort of immanent risk of bankruptcy for a firm (Kahneman et al., 1986; Bewley, 1995, 1999; Akerlof et al., 1996; Campbell and Kamlani, 1997; Kimura and Ueda, 2001; Fehr and Goette, 2005; Böckerman et al, 2010). Moreover, there is empirical evidence that extremely large demand shocks induce responses of hours and hourly wages, both for positive and negative shocks.

Furthermore, there is much macroeconomic empirical evidence pointing towards downward nominal wage rigidity. Kandil (1995) shows for a sample of 19 industrialized countries that in response to permanent monetary policy shocks wages generally respond stronger to positive shocks than to negative shocks of

downward nominal wage rigidity is introduced in an ad-hoc way, using a linex function as proposed by Varian (1974). (The only exception to this is Benigno and Ricci (2011), who use a case sensitive approach.) Consequently, these models exhibit permanent downward nominal wage rigidity, independent of the size and the sign of the shock. However, since the degree of downward nominal wage rigidity varies with the size of the shock, the short- and long-run Phillips curves are state-dependent, a feature not considered in the studies above. 
equal magnitude. Similar evidence in response to permanent aggregate demand shocks is provided by Kandil (2006) for United States industries and Kandil (2010) for a large variety of industrialized countries. ${ }^{2}$

There is a wide variety of current theories of wage adjustment, explaining nominal wage rigidity, in particular downward nominal wage rigidity. The most prominent theories are the contract theory (Fisher, 1977; Taylor, 1979), the implicit contract theory (Baily, 1974; Azariadis, 1975; Gordon, 1976; Stiglitz, 1986), the efficiency wage theory (Shapiro and Stiglitz, 1984; Akerlof et al., 1982; Weiss, 1980; Weiss, 1990), the fair wage hypothesis (Akerlof and Yellen, 1990), and the insider-outsider theory (Lindbeck and Snower, 1988). These theories aim at explaining, why firms avoid wage cuts or, in the case of the (implicit) contract theory, why wages are sluggish in general. However, none of these theories does take a stance on jointly explaining all three stylized empirical facts on wage adjustment outlined above.

In this paper we offer an new theory of downward nominal wage rigidity resting on worker loss aversion in the wage dimension. The resulting theory provides an account of asymmetric nominal wage rigidity in line with empirical evidence stated above. Although, there is no hard evidence for a direct link of worker loss aversion and downward nominal wage rigidity, there is ample indicative evidence for the existence of such a link. Dunn (1996) presents survey evidence from US labor markets and finds that the behavior of labor supply is consistent with the notion of loss averse workers. Similar evidence is also presented by Goette et al. (2004) and Fehr and Goette (2007).

Furthermore, there is a large literature that documents that relative pay matters for subjective well-being (Clark and Oswald, 1996). Workers evaluate their wages relative to a reference point, e.g. in the form of an implicit wage norm (Jaques, 1956, 1961), past earnings (Clark, 1999; Grund and Sliwka, 2007; Kawaguchi and Ohtake, 2007), or the earnings of others (Clark and Oswald, 1996; Clark et al, 2008). Falling behind reference points lowers life satisfaction and gives rise to negative morale effects. Supportive evidence for such morale effects is provided by, e.g. Kube et al. (2013) who document in a field experiment that there is a highly asymmetric reaction of work morale to positive and negative deviations from a reference wage. Similar evidence is provided by a field experiment by Chemin and Kurmann (2012). Survey evidence for the United States and various European economies suggests that amongst the most important factors for why firms do not adjust wages downward is the risk of negative effect to workers' morale (Campbell and Kamlani, 1997; Du Caju et al.,

\footnotetext{
${ }^{2}$ In addition to the asymmetric wage reaction in response to the permanent demand shock, Kandil $(1995,2006,2010)$ finds an asymmetric reaction of output. Output responds much stronger to permanent negative demand shocks than to positive ones, a feature which is implied by standard theories of downward nominal rigidities and, given standard production technologies, also predicted by our model. This asymmetry in output is further documented by a large empirical literature. While Delong and Summers (1988), Cover (1992), Kandil (2001), and Ravn and Sola (2004) provide evidence for the United States, Karras (1996), Lenz (1997), Kandil (1999), and Karras and Stokes (1999) provide evidence for a wide variety of industrialized countries. Finally, evidence for developing countries is given by Kandil (1998), Tan et al (2010), and Mehrara and Karsalari (2011).
} 
2014). However, Chen and Horton (2014) show that the effect on work morale vanishes if the wage cut is justified by reasonable arguments such as severe financial stress of the firm. Furthermore, Koch (2013) shows in an laboratory experiment that wage cuts in recessions are stronger in the absence of reference wages. If reference wages exist, wage cuts are cut down by approximately half the amount.

In our model, loss-averse workers evaluate wages relative to a reference wage. Kőszegi and Rabin (2006, 2007, 2009) and Heidhues and Köszegi (2005, 2008, forthcoming) argue that reference points are determined by agents' rational expectations about outcomes from the recent past. There is much empirical evidence suggesting that reference points are determined by expectations, in concrete situations such as in police performance after final offer arbitration (Mas, 2006), in the United States TV show "Deal or no Deal" (Post et al., 2008), with respect to domestic violence (Card and Dahl, 2011), in cab drivers' labor supply decisions (Crawford and Meng, 2011), or in the effort choices of professional golf players (Pope and Schweitzer, 2011). In the context of laboratory experiments, Knetsch and Wong (2009) and Marzilli Ericson and Fuster (2011) find supporting evidence from exchange experiments and Abeler et al. (2011) do so through an effort provision experiment. Endogenizing consumers' reference wages in this way allows our model to capture that current wage changes influence the consumers' future reference wage and thereby affect labor supply. That reference wages influence reservation wages via this effect is supported by experimental evidence of Falk et al. (2006) who introduce a minimum wage as reference point and show that this introduction leads to an increase in the subjects' reservation wage, whereas the removal of that minimum wage, only leads to marginal a reduction in reservation wage. These pieces of evidence are consonant with the assumptions underlying our analysis. Our analysis works out the implications of these assumptions for state-dependent wage sluggishness in the form of asymmetric wage adjustment for positive and negative labor demand shocks.

Of course, we are not the first to explain downward nominal wage rigidity with workers' loss aversion with respect to wages. McDonald and Sibly (2001) set up an insider-outsider model with wage bargaining, where workers are loss averse with respect to real wages and where the reference wage equals last period's wage, i.e. the status quo, as suggested by Kahnemann et al. (1991). They find that wages are rigid with respect to the reference wage, giving rise to real effects of monetary policy for expansionary monetary shocks. An analogous result is derived by Bhaskar (1990) in a model of union bargaining, where workers are loss averse with respect to their own wages relative to wages paid to members of other unions. Finally, Eliaz and Spiegler (2014) analyze loss averse workers in a restricted search and matching model. They follow Heihues and Köszegi and assume that reference points are determined by rational expectations from the recent past. Eliaz and Spiegler (2014) find that in response to productivity shocks, wages of newly hired workers are (imperfectly) flexible, whereas they are downward rigid for existing workers. While all these papers study the role of loss aversion on downward wage rigidity, neither of these papers can explain 
the empirical evidence on wages completely.

\section{Model}

We incorporate reference-dependent preferences and loss aversion into an otherwise standard model of monopsony on the labor market. Workers are loss averse with respect to wages. They evaluate wages relative to their reference wages, which depend on their rational wage expectations. Firms are monopsonists and can set their wages freely in each period to maximize their profits.

\subsection{Labor Supply Curve of the Loss Averse Worker}

We assume that workers are loss averse with respect to wage changes, i.e. the perceived utility losses from wage decreases relative to the reference wage are weighted more heavily than the perceived utility gains from wage increases of equal magnitude. This gives rise to a labor supply curve which is convexly kinked at the reference wage. In what follows, we assume that this labor supply curve is upward sloping, since the substitution effect of a wage change dominates the income effect. ${ }^{3}$ Consequently the employment increase associated with a wage increase is small relative to the employment decrease associated with a wage decrease of equal magnitude.

The worker's preferences in period $t$ are represented by the following utility function $^{4}$

$$
U_{t}\left(c_{t}, n_{t}\right)=U_{t}^{c}\left(c_{t}\right)-\theta_{i} \frac{n_{t}^{\vartheta_{i}}}{\vartheta_{i}}
$$

where $c_{t}$ is consumption in period $t, \theta_{i}$ is a shifting parameter that ensures continuity of the worker's preferences at the reference wage ${ }^{5}$ and $n_{t}$ is hours worked in period $t$. The parameter $\vartheta_{i}$ is an indicator function of the form

$$
\vartheta_{i}= \begin{cases}\vartheta_{1} & \text { for } w_{t}>w_{t}^{r}, \text { i.e. gain domain } \\ \vartheta_{2} & \text { for } w_{t}<w_{t}^{r} \text {, i.e. loss domain }\end{cases}
$$

which describes the degree of the worker's loss aversion and where $w_{t}$ and $w_{t}^{r}$ are the workers current wage and reference wage, respectively. For loss averse workers $\vartheta_{1}>\vartheta_{2}$, which implies that the worker's disutility of labor $U_{t}^{n}\left(n_{t}\right)=$ $\frac{n_{t}^{\vartheta_{i}}}{\vartheta_{i}}$ is steeper, i.e. the marginal disutility of labor is higher, in the gain domain than in the loss domain. Therefore, the workers willingness to work additional

\footnotetext{
${ }^{3}$ As long as labor is less responsive to wage increases (relative to the reference wage) than to wage decreases, it can be shown that our model can explain the above three empirical regularities on wage adjustment, irrespective of the sign of the slope of the labor supply curve. 1.

${ }^{4}$ In what follows, we normalize the worker's marginal utility of consumption $\frac{\delta U_{t}^{c}}{\delta c_{t}}$ equal to

${ }^{5}$ Therefore, it must hold that $\theta_{1}=\left(w^{r}\right)^{1-\frac{\lambda_{2}}{\lambda_{1}}} \theta_{2}^{\frac{\lambda_{2}}{\lambda_{1}}}$.
} 
hours is lower when the wage is above the worker's reference wage than when it is below.

Maximization of the utility function (1) subject to the simple budget constraint $c_{t}=w_{t} n_{t}$ yields the following kinked labor supply function

$$
n_{t}= \begin{cases}\left(\frac{w_{t}}{\theta_{1}}\right)^{\lambda_{1}} & \text { for } w_{t}>w_{t}^{r}, \text { i.e. gain domain } \\ \left(\frac{w_{t}}{\theta_{2}}\right)^{\lambda_{2}} & \text { for } w_{t}<w_{t}^{r}, \text { i.e. loss domain }\end{cases}
$$

where $\lambda_{i}=\frac{1}{\vartheta_{i}-1}$ denotes the Frisch elasticity of labor supply. Loss aversion with respect to wages implies that $\lambda_{1}<\lambda_{2}$, i.e. that the worker reacts stronger to wage decreases (by reducing employment, given the substitution effect dominates the income effect) than to wage increases relative to the reference wage $w_{t}^{r}$ (by increasing employment, given the substitution effect dominates the income effect). ${ }^{6}$

The kink, lying at the intersection of the two labor supply curves $n_{t}\left(w_{t}, \lambda_{1}, \theta_{1}\right)$ and $n_{t}\left(w_{t}, \lambda_{2}, \theta_{2}\right)$, is given by the wage-labor combination

$$
\left(\widehat{w_{t}}, \widehat{n_{t}}\right)=\left(w_{t}^{r},\left(\frac{\theta_{1}}{\theta_{2}}\right)^{\frac{1}{\lambda_{2}}-\frac{1}{\lambda_{1}}}\right),
$$

where "^" denotes the value of a variable at the kink.

The worker's reference wage $w_{t}^{r}$ is formed at the beginning of each period. In the spirit of Köszegi and Rabin (2006), we assume that the worker's reference wage depends on her rational wage expectation. Shocks materialize unexpectedly in the course of the period and therefore do not enter $I_{t}$, the information set available to the worker at the beginning of the period. Thus, the worker knows only with a one-period lag that a shock is permanent and can adjust her rational wage expectation accordingly. Thus the worker's reference wage is given by $w_{t}^{r}=E_{t-1}\left[w_{t} \mid I_{t-1}\right]$. Changes in the reference wage $w_{t}^{r}$ change the position of the kink of the worker's labor supply curve and also shift the labor supply curve as a whole. We follow Köszegi and Rabin (2006) and assume that the worker's expected wage implicitly determines the worker's endogenous income target. ${ }^{7}$ Thus, an increase in the expected wage raises her implicit income target, whereas a decrease in the expected wage lowers it. If, at the beginning at the period, the worker anticipates a higher (lower) wage for the following

\footnotetext{
${ }^{6}$ While this point is crucial for the predictions of our theory, it is worth pointing out that these results hold irrespective of the sign of the slope of the labor supply curve above the kink as long as the ratio of the absolute slopes above and below the kink remains unchanged (i.e. the labor supply curve is steeper above than below the kink). Thus, out theory does cover the evidence that the substitution effect always outweighs the income effect (upward sloping labor supply curve) as well as the evidence of, e.g., Köszegi and Rabin (2006) and others according to which we have a backward bending labor supply curve above the reference wage.

${ }^{7}$ If the labor demand curve is inelastic and the firm faces costs of labor adjustment (a realistic scenario, certainly for the short run), so that the profit-maximizing employment can take place in the inelastic portion of the labor demand curve, then increases in the reference wage translate one-to-one into increases in the reference income.
} 
period, i.e. her reference wage increases (decreases), she will supply relatively more (less) labor in order to reach her new higher (lower) implicit income target. From this, it follows that the worker's labor supply curve shifts outwards (inwards) in response to an upward (downward) adjustment of the worker's reference wage.

\subsection{The Firm's optimization problem}

Assuming that the output price $p$ is exogenously given at $p=1$, the firm maximizes its current period profit $\Pi_{t}=Y_{t}\left(n_{t}\right)-w_{t}\left(n_{t}\right) n_{t}$ taking into account the inverse of the worker's kinked labor supply function $w_{t}\left(n_{t}\right)=\theta_{i} n_{t}^{\frac{1}{\lambda_{i}}}$. The resulting first order condition of the firm's optimization problem reads as

$$
\frac{\partial \Pi_{t}}{\partial n_{t}}=\frac{\partial Y_{t}\left(n_{t}\right)}{\partial n_{t}}-w_{t}\left(n_{t}\right)-\frac{\partial w_{t}}{\partial n_{t}} n_{t}=0
$$

which is equivalent to

$M P L_{t}=\frac{\partial Y_{t}\left(n_{t}\right)}{\partial n_{t}}=w_{t}\left(n_{t}\right)+\frac{\partial w_{t}}{\partial n_{t}} n_{t}=\left(1+\frac{1}{\lambda}\right) w_{t}=\left(1+\frac{1}{\lambda}\right) \theta n_{t}^{\frac{1}{\lambda}}=M C L_{t}$.

In what follows we assume that the firm's production function is given by $Y_{t}\left(n_{t}\right)=c n_{t}^{\alpha}$ where $c>0$ and $0<\alpha<1$, so that the firm's labor demand function, given by its marinal product of labor $(M P L)$, is downward sloping: $L_{t}^{D}=M P L_{t}=c \alpha n_{t}^{(\alpha-1)}$.

Since the labor supply function of the loss averse worker is kinked at the reference wage $w^{r}$, the firm's real marginal cost of labor $(M C L)$ is discontinuous at the kink:

$$
M C L_{t}\left(\widehat{n_{t}}, \lambda_{i}, \theta_{i}\right)=\left(1+\frac{1}{\lambda_{i}}\right) \theta_{i}{\widehat{n_{t}}}^{\frac{1}{\lambda_{i}}} .
$$

The interval $\left[M C L_{t}\left(\widehat{n_{t}}, \lambda_{1}, \theta_{1}\right), M C L_{t}\left(\widehat{n_{t}}, \lambda_{2}, \theta_{2}\right)\right]$, where $M C L_{t}\left(\widehat{n_{t}}, \lambda_{1}, \theta_{1}\right)>$ $M C L_{t}\left(\widehat{n_{t}}, \lambda_{2}, \theta_{2}\right)$, we call "marginal cost discontinuity" $M C D_{t}\left(\widehat{n_{t}}, \lambda_{1}, \theta_{1}, \lambda_{2}, \theta_{2}\right)$.

We assume that in the initial steady state, the exogenously given reference wage is $w_{s s}^{r}$. Furthermore, in the steady state the firm's labor demand curve $(M P L)$ intersects the marginal cost discontinuity. To fix ideas, we assume that initially the labor supply curve crosses the midpoint of the discontinuity in the marginal cost curve $^{8}$, as depicted in Figure 1. This assumption permits us to derive the symmetry characteristics of wage and employment responses to positive and negative labor demand shocks. This implies that the firm's optimal wage in the initial steady state $w_{s s}^{*}$ is equal to $w_{s s}^{r}{ }^{9}$

\footnotetext{
${ }^{8}$ This implies that the slope parameter of the firm's labor demand function has to fulfill $c=\frac{M C L_{t}\left(\widehat{n_{t}}, \lambda_{1}, \theta_{1}\right)+M C L_{t}\left(\widehat{n_{t}}, \lambda_{2}, \theta_{2}\right)}{2 \alpha \widehat{n_{t}}(\alpha-1)}$.

${ }^{9}$ The proof is straightforward: Let $\nu$ be an arbitrarily small number. Then for wages equal to $w_{s s}^{r}+\nu$ the firm faces a situation in which marginal cost is higher than marginal revenue product and decreasing the wage would raise the firm's profit, while for wages equal
} 


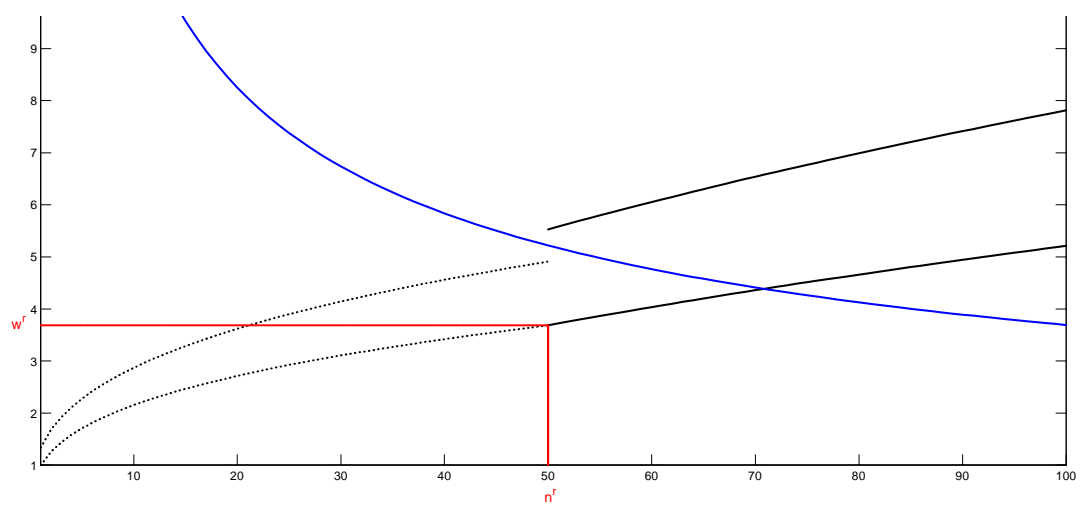

Figure 1: Initial problem of the monopsonistic firm

\section{Demand Shocks}

For simplicity, we analyse the firm's wage setting reaction in response to permanent labor demand shocks in a two-period context. These labor demand shocks, represented by $\varepsilon_{t}$, are unexpected and enter the labor demand function multiplicatively:

$$
L_{t}^{D}=c \alpha n_{t}^{(\alpha-1)} \varepsilon_{t}
$$

We consider the effects of a shock that hits the economy in period $t=0$. We define a "small" shock as one that leaves the labor demand curve passing through the marginal cost discontinuity, and a "large" shock as one that shifts the labor demand curve sufficiently so that it no longer passes through the marginal cost discontinuity.

The maximum size of a small shock for the labor demand function (8) is

$$
\overline{\varepsilon_{t}}\left(\lambda_{i}, \theta_{i}\right)=\frac{\left(1+\frac{1}{\lambda_{i}}\right) \theta_{i}}{c \alpha} \widehat{n_{s s}} \frac{1}{\lambda_{i}}-(\alpha-1)
$$

i.e. $\overline{\varepsilon_{t}}\left(\lambda_{i}, \theta_{i}\right)$ is the shock size for which the shifted labor demand curve lies exactly on the boundaries of the marginal cost discontinuity $M C D_{t}\left(\widehat{n_{t}}, \lambda_{1}, \theta_{1}, \lambda_{2}, \theta_{2}\right) .{ }^{10}$ In the analysis that follows, we will distinguish between small and large permanent labor demand shocks.

to $w_{s s}^{r}-\nu$ the firm faces a situation in which marginal cost is lower than marginal revenue product and increasing the wage would raise the firm's profit. Thus $w_{s s}^{*}=w_{s s}^{r}$ has to be the profit maximizing wage in the initial steady state.

${ }^{10}$ For $\bar{\varepsilon}\left(\lambda_{1}\right)$, the labor demand curve intersects the marginal cost gap on the upper bound, whereas for $\bar{\varepsilon}\left(\lambda_{2}\right)$ it intersects it on the lower bound. 


\subsection{Small labor demand shocks}

As noted, for a sufficiently small demand shock $\overline{\varepsilon_{0}}\left(\lambda_{2}, \theta_{2}\right) \leq \varepsilon_{0}^{s} \leq \overline{\varepsilon_{0}}\left(\lambda_{1}, \theta_{1}\right)$ the labor demand curve still intersects the marginal cost discontinuity, i.e. $L_{0}^{D}\left(\widehat{n_{t}}\right) \in M C D_{t}\left(\widehat{n_{t}}, \lambda_{1}, \theta_{1}, \lambda_{2}, \theta_{2}\right)$. Therefore, the prevailing steady state wage, which is equal to the worker's current reference wage, remains the firm's profitmaximizing wage, ${ }^{11}$ i.e. $w_{0}^{*}=w_{s s}^{*}=w_{s s}^{r}$, and we have complete wage rigidity. Accordingly, the profit-maximizing amount of labor remains unchanged as well: $\Delta n_{0}^{*}=0$. This holds true irrespective of the sign of the small labor demand shock.

\subsection{Large labor demand shocks}

For the analysis of wage adjustment in response to large variations in labor demand it proves useful to suppose, for the moment, that the worker's reference wage is exogenously fixed and does not change.

In contrast to the small labor demand shock, for a large shock, i.e. $\varepsilon_{0}^{l}>$ $\overline{\varepsilon_{0}}\left(\lambda_{1}, \theta_{1}\right)$ or $\varepsilon_{0}^{l}<\overline{\varepsilon_{0}}\left(\lambda_{2}, \theta_{2}\right)$, both, a wage and a labor reaction are induced. The new profit-maximizing wage of the firm is

$$
w_{0}^{*}=\theta_{i}\left[\frac{\left(1+\frac{1}{\lambda_{i}}\right) \theta_{i}}{c \alpha \varepsilon_{0}^{l}}\right]^{\frac{1}{\lambda_{i}(\alpha-1)-1}},
$$

while its corresponding profit-maximizing amount of labor is

$$
n_{0}^{*}=\left[\frac{\left(1+\frac{1}{\lambda_{i}}\right) \theta_{i}}{c \alpha \varepsilon_{0}^{l}}\right]^{\frac{1}{(\alpha-1)-\frac{1}{\lambda_{i}}}},
$$

where $\lambda_{i}=\lambda_{1}, \theta_{i}=\theta_{1}$ for positive and $\lambda_{i}=\lambda_{2}, \theta_{i}=\theta_{2}$ for negative shocks, respectively. Wages are relatively downward sluggish (i.e. less responsive to negative than to positive shocks), while for the optimal amount of labor this asymmetry reverses. The intuition is obvious once we decompose the large labor demand shock into the maximum small shock and the remainder:

$$
\varepsilon_{0}^{l}=\overline{\varepsilon_{0}}\left(\lambda_{i}, \theta_{i}\right)+\varepsilon_{0}^{r e m} .
$$

From our theoretical analysis above, the maximum small shock $\overline{\varepsilon_{0}}\left(\lambda_{i}, \theta_{i}\right)$ has no wage effects and no effects on the optimal quantity of labor. This holds true irrespective of the sign of the shock. By contrast, the remaining shock $\varepsilon_{0}^{r e m}$ has asymmetric effects. Let $\overline{n_{0}}$ be the quantity corresponding to $\overline{\varepsilon_{0}}\left(\lambda_{i}, \theta_{i}\right)$. Then the change in the optimal amont of labor in response to $\varepsilon_{0}^{r e m}$ is given by

$$
\Delta n_{0}^{r e m}=\frac{n_{0}^{*}}{\overline{n_{0}}}=\left(\frac{\varepsilon_{0}^{r e m}}{\overline{\varepsilon_{0}}\left(\lambda_{i}, \theta_{i}\right)}\right)^{\frac{1}{(\alpha-1)-\frac{1}{\lambda_{i}}}}
$$

\footnotetext{
${ }^{11}$ Compare the proof above.
} 
As can be seen from equation (13), the change of quantity in response to $\varepsilon_{0}^{r e m}$ depends positively on $\lambda_{i}$, the Frisch elasticity of labor supply. Since for the loss averse worker $\lambda_{1}<\lambda_{2}$, the labor reaction of the firm facing loss-averse workers is smaller in response to large positive labor demand shocks than to large negative ones of equal magnitude. This however implies that wages are less responsive to negative than to positive large labor demand shocks, because the former move the firm along the relatively flat portion of the labor supply curve, whereas the latter move it along the relatively steep portion of the labor supply curve.

Accounting for the adjustment of the worker's reference wage in response to large permanent shocks reinforces the results derived thus far. As discussed above, a large permanent labor demand shock induces a wage and a labor reaction in the shock period $t=0$. Accordingly the worker's reference wage adjusts at the beginning of the following period $t=1$, i.e. $w_{1}^{r}=E_{0}\left[w_{1} \mid I_{0}\right]=w_{0}^{*}$, which triggers an outward shift of the worker's labor supply curve for positive labor demand shocks and an inward shift for negative labor demand shocks.

Assuming that the shift of the worker's labor supply curve in response to an adjustment of the worker's reference wage from $w_{0}^{r}$ to $w_{1}^{r}$ leaves the labor demand curve passing through the marginal cost discontinuity ${ }^{12}$, the firm's optimal wage in period $t=1$ remains unchanged, i.e. $w_{1}^{*}=w_{0}^{* 13}$. By contrast, the optimal amount of labor in period $t=1$ changes due to the shift of the worker's labor supply curve. More specifically, for an upward adjustment of the worker's reference wage the optimal amount of labor $n_{1}^{*}$ increases, while it decreases for a downward adjustment of the worker's reference wage. This implies that in period $t=1$ the firm's profit is higher than in the shock period $t=0$ for positive permanent shocks, while it is lower for negative permanent shocks due to the worker's labor supply reaction in response to the change of her implicit income target ${ }^{14}$.

Since the firm anticipates this, the following incentives arise: In response to a large positive labor demand shock, the firm could raise the wage above the optimal wage $w_{0}^{*}$ in order to induce a stronger outward shift of the worker's labor supply curve in the following period. By contrast, in response to a large negative labor demand shock, the firm could try to dampen or avoid the inward shift of the worker's labor supply curve in the next period by lowering the wage less than otherwise optimal or by not lowering the wage at all ${ }^{15}$. Whether or not this occurs, generally depends on whether the firm's gain from an upward deviation from the optimal wage $w_{0}^{*}$ in terms of future profits (due to the relative

\footnotetext{
${ }^{12}$ If the shift of the labor supply curve is sufficiently strong so that the labor demand curve no longer passes through the marginal cost discontinuity, a new wage reaction in the opposite direction is induced which dampens the effects described below. However, since the following results still hold qualitatively, we do not consider this case in more detail.

${ }^{13}$ Compare the proof above.

${ }^{14}$ Intuitively, the firm can employ more labor for the same optimal wage $w_{1}^{*}=w_{0}^{*}$ in the case of a large positive labor demand shock, whereas it must employ less labor in the case of a large negative labor demand shock.

${ }^{15}$ Note that setting a wage below $w_{0}^{*}$ is never an option for the firm since it negatively affects future profits.
} 


\begin{tabular}{lcc}
\hline \hline Parameter & Symbol & Value \\
\hline Discount rate & $\beta$ & 0.99 \\
Frisch elasticity of labor supply (gain domain) & $\lambda_{1}$ & 1 \\
Frisch elasticity of labor supply (loss domain) & $\lambda_{2}$ & 2 \\
Loss aversion & $\kappa$ & 2 \\
Alpha & $\alpha$ & $2 / 3$ \\
\hline \hline
\end{tabular}

Table 1: Base calibration

rise in the reference wage) exceeds the firm's loss in terms of present profits (due to not setting the profit maximizing wage), i.e. whether $\Pi_{1}\left(w_{1}^{r}=w_{0}^{\prime}\right)+$ $\Pi_{0}\left(w_{0}^{\prime}\right)>\Pi_{1}\left(w_{1}^{r}=w_{0}^{*}\right)+\Pi_{0}\left(w_{0}^{*}\right)$ where $w_{0}^{\prime}>w_{0}^{*}$. To analyze which effect dominates, we calibrate the model and solve it numerically.

\subsection{Numerical analysis}

We calibrate the model for a quarterly frequency in accordance with standard values in the literature. We assume an annual interest rate of 4 percent, which yields a discount factor $\beta=0.99$. Loss aversion is measured by the relative slopes of the demand curves in the gain and loss domain, i.e. $\kappa=\frac{\lambda_{2}}{\lambda_{1}}$. The empirical literature on loss aversion in prices finds that losses induce demand reactions approximately twice as large as gains (Tversky and Kahnemann, 1991; Putler, 1992; Hardie et al., 1993; Griffin and Schulman, 2005; Adeyemi and Hunt, 2007). Therefore, we set $\kappa=2$. Following Galí (2008), we set $\alpha=2 / 3$ and $\lambda_{1}=1$, which is also close to the values chosen by Smets and Wouters (2003) and Christiano et al. (2005). The base calibration is summarized in Table 1.

According to our numerical analysis the firm's wage reaction in response to large permanent labor demand shocks depends crucially on the size and the sign of the shock. Tables 2 and table 3 present the numerical results of our base calibration in the two-period model. In the tables we report the shock-arcelasticities of wage $\left(\widetilde{\eta}_{\varepsilon, w}=\frac{\% \Delta w}{\% \Delta \varepsilon}\right)$ in the period of the shock $t=0$ for positive and negative permanent labor demand shocks for the firm facing loss averse workers. We find that wages are completely rigid for small positive and negative permanent labor demand shocks, while they are relatively downward sluggish for larger shocks. Moreover, for a certain range of medium sized shocks, wages are completely downward rigid but upwards flexible.

These results can be interpreted as follows. For large negative permanent demand shocks $\varepsilon_{0}^{l}<\overline{\varepsilon_{0}}\left(\lambda_{2}, \theta_{2}\right)$ the firm always has an incentive to deviate upwards from $w_{0}^{*}$, the optimal wage given by equation (10), and set $w_{0}^{\prime}$ instead, because it wishes to dampen the inward shift of the worker's labor supply curve due to the adjustment in the worker's reference wage in the next period. However, depending on the size of the large negative labor demand shock this either means lowering the wage less than $w_{0}^{*}$ or not adjusting the wage at all. More precisely for $\varepsilon_{0}^{l}<\varepsilon_{0}^{* *}\left(\lambda_{2}, \theta_{2}\right)$, the firm sets the wage $w_{0}^{\prime}$ such that $w_{s s}^{*}>w_{0}^{\prime}>w_{0}^{*}$, while for $\varepsilon_{0}^{* *}\left(\lambda_{2}, \theta_{2}\right)<\varepsilon_{0}^{l}<\overline{\varepsilon_{0}}\left(\lambda_{2}, \theta_{2}\right)$ the firm does not adjust the wage, i.e. 


\begin{tabular}{ll}
\hline \hline & $\widetilde{\eta}_{\varepsilon, w}$ \\
\hline$\varepsilon_{0}^{l}=0,99$ & 0 \\
$\varepsilon_{0}^{l}=0,90$ & 0 \\
$\varepsilon_{0}^{l}=0,75$ & 0 \\
$\varepsilon_{0}^{l}=0,65$ & 0.0655 \\
$\varepsilon_{0}^{l}=0,50$ & 0.1526 \\
$\varepsilon_{0}^{l}=0,25$ & 0.2301 \\
$\varepsilon_{0}^{l}=0,15$ & 0.2454 \\
$\varepsilon_{0}^{l}=0,05$ & 0.2718 \\
\hline \hline
\end{tabular}

Table 2: Shock elasticities of wage in $t=0$ to negative permanent labor demand shocks, $\overline{\varepsilon_{0}}\left(\lambda_{2}, \theta_{2}\right)=0.8571$

\begin{tabular}{ll}
\hline \hline & $\widetilde{\eta}_{\varepsilon, w}$ \\
\hline$\varepsilon_{0}^{l}=1,01$ & 0 \\
$\varepsilon_{0}^{l}=1,10$ & 0 \\
$\varepsilon_{0}^{l}=1,25$ & 0.3579 \\
$\varepsilon_{0}^{l}=1,35$ & 0.3801 \\
$\varepsilon_{0}^{l}=1,50$ & 0.4524 \\
$\varepsilon_{0}^{l}=1,75$ & 0.5020 \\
$\varepsilon_{0}^{l}=1,85$ & 0.5119 \\
$\varepsilon_{0}^{l}=1,95$ & 0,5188 \\
\hline \hline
\end{tabular}

Table 3: Shock elasticities of wage in $t=0$ to positive permanent labor demand shocks, $\overline{\varepsilon_{0}}\left(\lambda_{2}, \theta_{2}\right)=1.1429$

$w_{0}^{\prime}=w_{s s}^{*} \cdot{ }^{16}$

By contrast, for large positive permanent demand shocks $\varepsilon_{0}^{l}>\overline{\varepsilon_{0}}\left(\lambda_{1}, \theta_{1}\right)$ the firm always adjusts the wage upwards. However, our results also indicate that the firm does not always set a wage $w_{0}^{\prime}$ that is higher than $w_{0}^{*}$ for very large positive permanent labor demand shocks. If the shock exceeds a certain threshold, i.e. $\varepsilon_{0}^{l}>\varepsilon_{0}^{* *}\left(\lambda_{1}, \theta_{1}\right)$, the firm's loss in terms of present profits from not setting $w_{0}^{*}$ is not compensated by the gain in terms of future profits. Thus only for $\varepsilon_{0}^{* *}\left(\lambda_{1}, \theta_{1}\right)>\varepsilon_{0}^{l}>\overline{\varepsilon_{0}}\left(\lambda_{1}, \theta_{1}\right)$ the firm set the wage $w_{0}^{\prime}$ such that $w_{0}^{\prime}>w_{0}^{*} \cdot{ }^{17}$

\section{Conclusion}

With our theory of wage adjustment under loss aversion we are able to provide a complete account of the most stylized facts on wages. In particular, we can

\footnotetext{
${ }^{16}$ In our numerical anlysis $\varepsilon_{0}^{* *}\left(\lambda_{2}, \theta_{2}\right)=0,7060$, while the critical shock $\overline{\varepsilon_{0}}\left(\lambda_{2}, \theta_{2}\right)=$ 0,8571 .

${ }^{17}$ In our numerical anlysis $\varepsilon_{0}^{* *}\left(\lambda_{1}, \theta_{1}\right)=1,2849$, while the critical shock $\overline{\varepsilon_{0}}\left(\lambda_{1}, \theta_{1}\right)=$ 1,1429 .
} 
explain wage freezes, why firms are reluctant to cut wages in "normal" times as well as the existence of wage cuts in strong recessions.

In contrast to the New Keynesian literature, our explanation of wage adjustment is thoroughly microfounded, without recourse to ad hoc assumptions.

Furthermore, our model needs to be incorporated into a general equilibrium setting to validate the predictions of our theory.

\section{References}

Abeler, J., A. Falk, L. Goette, and D. Huffman (2011). Reference points and effort provision. American Economic Review 101(2), 470-492.

Abo-Zaid, S. (2013). Optimal monetary policy and downward nominal wage rigidity in frictional labor markets. Journal of Economic Dynamics and Control $37(1), 345-364$.

Agell, J. and P. Lundborg (2003). Survey evidence on wage rigidity and unemployment: Sweden in the 1990s. Scandinavian Journal of Economics 105(1), $15-30$.

Ahrens, S., I. Pirschel and D. Snower (2014). A theory of price adjustment under loss aversion. Kiel Working Paper 1915.

Akerlof, G.A. (1982). Labor contracts as partial gift exchange. The Quarterly Journal of Economics 97(4), 543-569.

Akerlof, G.A., W.R. Dickens, and G.L. Perry (1996). The macroeconomics of low inflation. Brookings Papers on Economic Activity 27(1), 1-76.

Akerlof, G.A. and J.L. Yellen (1990). The fair wage-effort hypothesis and unemployment. The Quarterly Journal of Economics 105(2), 255-283.

Altonji, J.G. and P.J. Devereux (1999). The extent and consequences of downward nominal wage rigidity. NBER Working Papers 7236, National Bureau of Economic Research, Inc.

Azariadis, A. (1975). Implicit contracts and underemployment equilibria. Journal of Political Economy 83(6), 1183-1202.

Babecký, J., P. Du Caju, T. Kosma, M. Lawless, J. Messina, and T. Rõõm (2010). Downward nominal and real wage rigidity: Survey evidence from European firms. Scandinavian Journal of Economics 112(4), 884-910.

Baily, M.N. (1974). Wages and employment under uncertain demand. Review of Economic Studies 41(1), 37-50. 
Benigno, P. and L.A. Ricci (2011). The inflation-output trade-off with downward wage rigidities. The American Economic Review 101(4), 1436-1466.

Bhaskar, V. (1990). Wage relativities and the natural range of unemployment. Economic Journal 100(400), 60-66.

Bauer, T., H. Bonin, L. Goette, and U. Sunde (2007). Real and nominal wage rigidities and the rate of inflation: Evidence from West German micro data. Economic Journal 117(524), F508-F529.

Bewley, T.F. (1995). A depressed labor market as explained by participants. American Economic Review 85(2), 250-254.

Bewley, T.F. (1999). Why wages don't fall during a recession. Harvard University Press. Cambridge.

Blundell, R., C. Crawford, and W. Jin (2014). What can wages and employment tell us about the UK's productivity puzzle? Economic Journal 0(576), 377-407.

Böckerman, P., S. Laaksonen, and J. Vainiomäki (2010). Micro and macro level wage rigidity: Lessons from Finland. Finnish Economic Papers 23(1), 27-42.

Campbell, C.M. and K.S. Kamlani (1997). The reasons for wage rigidity: Evidence from a survey of firms. The Quarterly Journal of Economics 112(3), 759-789.

Card, D. and G.B. Dahl (2011). Family violence and football: The effect of unexpected emotional cues on violent behavior. The Quarterly Journal of Economics 126(1), 103-143.

Card, D. and D. Hyslop (1997). Does inflation "grease the wheels of the labor market"? NBER Chapters. In: C.D. Romer and D.H. Romer (eds.), Reducing Inflation: Motivation and Strategy, National Bureau of Economic Research, pp. $71-122$.

Carlsson, M. and A. Westermark (2008). Monetary policy under downward nominal wage rigidity. The B.E. Journal of Macroeconomics 8(1), 1-61.

Carrington, W.J. (1996). The Alaskan labor market during the pipeline era. Journal of Political Economy 104(1), 186-218.

Chen, D.L. and J.J. Horton (2014). The wages of pay cuts: Evidence from a field experiment. mimeo.

Chemin, M. and A. Kurmann (2012). Do workers feel entitled to high wages? Evidence from a tong term field experiment. Federal Reserve Board Mimeo, 
2012.

Christiano, L.J., M. Eichenbaum and C.L. Evans (2005). Nominal rigidities and the dynamic effects of a shock to monetary policy. Journal of Political Economy 113(1), 1-45.

Clark, A.E. (1999). Are wages habit-forming? Evidence from micro data. Journal of Economic Behavior \& Organization 39(2), 179-200.

Clark, A.E., P. Frijters and M.A. Shields (2008). Relative income, happiness, and utility: An explanation for the Easterlin paradox and other puzzles. Journal of Economic Literature 46(1), 95-144.

Clark, A.E. and A.J. Oswald (1996). Satisfaction and comparison income. Journal of Public Economics 61(3), 359-381.

Cobb, M. and L. Opazo (2008). Microeconomic evidence of nominal wage rigidity in Chile. Working Papers Central Bank of Chile 496, Central Bank of Chile.

Cover, J.P. (1992). Asymmetric effects of positive and negative money-supply shocks. The Quarterly Journal of Economics 107(4), 1261-1282.

Crawford, V.P. and J. Meng (2011). New York City cab drivers' labor supply revisited: Reference-dependent preferences with rational-expectations targets for hours and income. American Economic Review 101(5), 1912-1932.

DeLong, J.B. and L.H. Summers (1988). How does macroeconomic policy affect output? Brookings Papers on Economic Activity 19(2), 433-494.

Dickens, W.T., L. Goette, E.L. Groshen, S. Holden, J. Messina, M.E. Schweitzer, J. Turunen, M.E. Ward (2007). How wages change: Micro evidence from the International Wage Flexibility Project. Journal of Economic Perspectives 21(2), 195-214.

Du Caju, P., T. Kosma, M. Lawless, J. Messina, and T. Rõõm (2014). Why firms avoid cutting wages: Survey evidence from European firms. Policy Research Working Paper Series 6976, The World Bank.

Dunn, L.F. (1996). Loss aversion and adaptation in the labor market: Empirical indifference functions and labor supply. The Review of Economics and Statistics 78(3), 441-450.

Eliaz, K. and R. Spiegler (2014). Reference dependence and labor market fluctuations. NBER Chapters. In: J.A. Parker and M. Woodford (eds), NBER Macroeconomics Annual 2013, volume 28, pages 159-200, National Bureau of 
Economic Research, Inc.

Fagan, G. and J. Messina (2009). Downward nominal wage rigidity and optimal steady-state inflation. Working Paper Series No. 1048, European Central Bank.

Fahr, S. and F. Smets (2010). Downward wage rigidities and optimal monetary policy in a monetary union. Scandinavian Journal of Economics 112(4), 812-840.

Falk, A., E. Fehr, and C. Zehnder (2006). Fairness perceptions and reservation wages - the behavioral effects of minimum wage laws. The Quarterly Journal of Economics 121(4), 1347-1381.

Fehr, E. and L. Goette (2005). Robustness and real consequences of nominal wage rigidity. Journal of Monetary Economics 52(4), 779-804.

Fehr, E. and L. Goette (2007). Do workers work more if wages are high? Evidence from a randomized field experiment. American Economic Review 97(1), 298-317.

Fischer, S. (1977). Long-term contracts, rational expectations, and the optimal money supply rule. Journal of Political Economy 85(1), 191-205.

Galí, J. (2008). Monetary Policy, Inflation, and the Business Cycle: An Introduction to the New Keynesian Framework. Princeton University Press.

Goodfriend, M. and R. King (1997). The new neoclassical synthesis and the role of monetary policy. NBER Chapters. In: NBER Macroeconomics Annual 1997, Volume 12, pages 231-296, National Bureau of Economic Research, Inc.

Gordon, D.F. (1976). A neo-classical theory of keynesian unemployment. CarnegieRochester Conference Series on Public Policy 1(1), 65-97.

Gottschalk, P. (2005). Downward nominal-wage flexibility: Real or measurement error? The Review of Economics and Statistics 87(3), 556-568.

Goette, L., D. Huffman, and E. Fehr (2004). Loss aversion and labor supply. Journal of the European Economic Association 2(2-3), 216-228.

Grund, C. and D Sliwka (2007). Reference-dependent preferences and the impact of wage increases on job satisfaction: Theory and evidence. Journal of Institutional and Theoretical Economics 163(2), 313-335.

Heidhues, P. and B. Köszegi (2005). The impact of consumer loss aversion on pricing. CEPR Discussion Papers No. 4849, Centre for Economic Policy Research. 
Heidhues, P. and B. Kőszegi (2008). Competition and price variation when consumers are loss averse. American Economic Review 98(4), 1245-1268.

Heidhues, P. and B. Köszegi (forthcoming). Regular prices and sales. Theoretical Economics, forthcoming.

Iregui B., A.M., L.A. Melo B., and M.T. RamÃ-rez G. (2009). Are wages rigid in Colombia?: Empirical evidence based on a sample of wages at the firm level. Borradores de Economia 571i, Banco de la Republica de Colombia.

Jaques, E. (1956). Measurement of responsibility. A study of work, Payment, and Individual Capacity. London: Tavistock Publications.

Jaques, E. (1961). Equitable payment: A general theory of work, differential payment, and individual progress. London: Heinemann.

Kahn, S. (1997). Evidence of nominal wage stickiness from microdata. American Economic Review 87(5), 993-1008.

Khan, A., King, R.G. and A.L. Wolman (2003). Optimal monetary policy. Review of Economic Studies 70(4), 825-860.

Kahneman, D., J.L. Knetsch, and R. Thaler (1986). Fairness as a constraint on profit seeking: Entitlements in the market. American Economic Review 76(4), 728-741.

Kahneman, D., J.L. Knetsch, and R.H. Thaler (1991). Anomalies: The endowment effect, loss aversion, and status quo bias. Journal of Economic Perspectives 5(1), 193-206.

Kandil, M. (1995). Asymmetric nominal flexibility and economic fluctuations. Southern Economic Journal 61(3), 674-695.

Kandil, M. (1998). Supply-side asymmetry and the non-neutrality of demand fluctuations. Journal of Macroeconomics 20(4), 785-809.

Kandil, M. (1999). The asymmetric stabilizing effects of price flexibility: Historical evidence and implications. Applied Economics 31(7), 825-839.

Kandil, M. (2001). Asymmetry in the effects of US government spending shocks: Evidence and implications. The Quarterly Review of Economics and Finance 41(2), 137-165.

Kandil, M. (2006). Asymmetric effects of aggregate demand shocks across U.S. industries: Evidence and implications. Eastern Economic Journal 32(2), 259283. 
Kandil, M. (2010). The asymmetric effects of demand shocks: international evidence on determinants and implications. Applied Economics 42(17), 2127-2145.

Karras, G. (1996). Why are the effects of money-supply shocks asymmetric? Convex aggregate supply or "pushing on a string"? Journal of Macroeconomics 18(4), 605-619.

Karras, G. and H.H. Stokes (1999). On the asymmetric effects of money-supply shocks: International evidence from a panel of OECD countries. Applied Economics 31(2), 227-235.

Kawaguchi, D. and F. Ohtake (2007). Testing the morale theory of nominal wage rigidity. Industrial and Labor Relations Review 61(1), 59-74.

Kim, J. and F.J. Ruge-Murcia (2009). How much inflation is necessary to grease the wheels? Journal of Monetary Economics 56(3), 365-377.

Kim, J. and F.J. Ruge-Murcia (2011). Monetary policy when wages are downwardly rigid: Friedman meets Tobin. Journal of Economic Dynamics and Control 35(12), 2064-2077.

Kimura, T. and K. Ueda (2001). Downward nominal wage rigidity in Japan. Journal of the Japanese and International Economies 15(1), 50-67.

Knetsch, J.L. and W.-K. Wong (2009). The endowment effect and the reference state: Evidence and manipulations. Journal of Economic Behavior \& Organization $71(2), 407-413$.

Koch, C. (2013). Do reference points lead to wage rigidity? Experimental evidence. Mimeo.

Kube, S., M.A. Mar'echal, and C. Puppe (2013). Do wage cuts damage work morale? Evidence from a natural field experiment. Journal of the European Economic Association 11(4), 853-870.

Köszegi, B. and M. Rabin (2006). A model of reference-dependent preferences. The Quarterly Journal of Economics 121(4), 1133-1165.

Kőszegi, B. and M. Rabin (2007). Reference-dependent risk attitudes. American Economic Review 97(4), 1047-1073.

Kőszegi, B. and M. Rabin (2009). Reference-dependent consumption plans. American Economic Review 99(3), 909-936. 
Lebow, D.E., R.E. Saks, and B.A. Wilson (2003). Downward nominal wage rigidity: Evidence from the employment cost index. The B.E. Journal of Macroeconomics 3(1), 1-30.

Lenz, C. (1997). Asymmetric effects of monetary policy in Switzerland. Swiss Journal of Economics and Statistics 133(III), 441-454.

Lindbeck, A. and D.J. Snower (1988). The insider-outsider theory of employment and unemployment. MIT Press, Cambridge, MA.

Marzilli Ericson, K.M. and A. Fuster (2011). Expectations as endowments: Evidence on reference-dependent preferences from exchange and valuation experiments. The Quarterly Journal of Economics 126(4), 1879-1907.

Mas, A. (2006). Pay, reference pay and police performance. The Quarterly Journal of Economics 121(3), 783-821.

McDonald, I.M. and H. Sibly (2001). How monetary policy can have permanent real effects with only temporary nominal rigidity. Scottish Journal of Political Economy 48(5), 532-546.

McLaughlin, K.J. (1994). Rigid wages? Journal of Monetary Economics 34(3), 383-414.

Mehrara, M. and A.R. Karsalari (2011). Asymmetric effects of monetary shocks on economic activities: The case of Iran. Journal of Money, Investment and Banking 20, 62-74.

Nickell, S. and G. Quintini (2003). Nominal wage rigidity and the rate of inflation. Economic Journal 113(490), 762-781.

Pope, D.G. and M.E. Schweitzer (2011). Is Tiger Woods loss averse? Persistent bias in the face of experience, competition, and high stakes. American Economic Review 101(1), 129-157.

Post, T., M.J. van den Assem, G. Baltussen, and R.H. Thaler (2008). Deal or no deal? Decision making under risk in a large-payoff game show. American Economic Review 98(1), 38-71.

Ravn, M.O. and M. Sola (2004). Asymmetric effects of monetary policy in the United States. Federal Reserve Bank of St. Louis Review 86(5), 41-60.

Shapiro, C. and J.E. Stiglitz (1984). Equilibrium unemployment as a worker discipline device. American Economic Review 74(3), 433-444. 
Sigurdsson, J. and R. Sigurdardottir (2011). Evidence of nominal wage rigidity and wage setting from Icelandic microdata. Economics wp55, Department of Economics, Central bank of Iceland.

Smets, F. and R. Wouters (2003). An estimated dynamic stochastic general equilibrium model of the euro area. Journal of the European Economic Association 1(5), 1123-1175.

Smith, J.C. (2000). Nominal wage rigidity in the United Kingdom. The Economic Journal 110(462), 176-195.

Stiglitz, J.E. (1986). Theories of wage rigidity. In: J.L. Butkiewicz, K.J. Koford, and J.B. Miller (eds.), Keynes' Economic Legacy: Contemporary Economic Theories, New York: Praeger Publishers, 153-206.

Tan, S.-H., M.-S. Habibullah, and A. Mohamed (2010). Asymmetric effects of monetary policy in ASEAN-4 economies. International Research Journal of Finance and Economics 44, 30-42.

Taylor, J.B. (1979). Staggered wage setting in a macro model. American Economic Review 69(2), 108-113.

Varian, H. (1974). A Bayesian approach to real estate assessment. In: S.E. Feinberg and A. Zellner (eds.), Studies in Bayesian Economics in Honour of L.J. Savage. North-Holland, Amsterdam.

Weiss, A.W. (1980). Job queues and layoffs in labor markets with flexible wages. Journal of Political Economy 88(3), 526-538.

Weiss, A.W. (1990). Efficiency wages: Models of unemployment, layoffs, and wage dispersion. Princeton University Press. Princeton. 